\title{
Dynamic telescopic craniotomy: a cadaveric study of a novel device and technique
}

\author{
Rohit Khanna, MD, ${ }^{1,2}$ and Lisa Ferrara, $\mathrm{PhD}^{3}$ \\ ${ }^{1}$ Neurosurgery Service, Halifax Health; ${ }^{2}$ Florida State University College of Medicine, Daytona Beach, Florida; and ${ }^{3}$ OrthoKinetic \\ Technologies LLC, Southport, North Carolina
}

\begin{abstract}
OBJECTIVE The authors assessed the feasibility of the dynamic decompressive craniotomy technique using a novel cranial fixation plate with a telescopic component. Following a craniotomy in human cadaver skulls, the telescopic plates were placed to cover the bur holes. The plates allow constrained outward movement of the bone flap upon an increase in intracranial pressure (ICP) and also prevent the bone flap from sinking once the ICP normalizes. The authors compared the extent of postcraniotomy ICP control after an abrupt increase in intracranial volume using the dynamic craniotomy technique versus the standard craniotomy or hinge craniotomy techniques.
\end{abstract}

METHODS Fixation of the bone flap after craniotomy was performed in 5 cadaver skulls using 3 techniques: 1) dynamic telescopic craniotomy, 2) hinge craniotomy, and 3) standard craniotomy with fixed plates. The ability of each technique to allow for expansion during intracranial hypertension was evaluated by progressively increasing intracranial volume. Biomechanical evaluation of the telescopic plates with load-bearing tests was also undertaken.

RESULTS Both the dynamic craniotomy and the hinge craniotomy techniques provided significant control of ICP during increases in intracranial volume as compared with the standard craniotomy technique. With the standard craniotomy, ICP increased from a mean of 11.4 to $100.1 \mathrm{~mm} \mathrm{Hg}$ with the addition of $120 \mathrm{ml}$ of intracranial volume. However, with the dynamic craniotomy, the addition of $120 \mathrm{ml}$ of intracranial volume increased the ICP from a mean of 2.8 to $13.4 \mathrm{~mm} \mathrm{Hg}$, maintaining ICP within the normal range as compared with the standard craniotomy $(p=0.04)$. The dynamic craniotomy was also superior in controlling ICP as compared with the hinge craniotomy, providing expansion for an additional $40 \mathrm{ml}$ of intracranial volume while maintaining ICP within a normal range $(p=0.008)$. Biomechanical load-bearing tests for the dynamic telescopic plates revealed rigid restriction of bone-flap sinking as compared with standard fixation plates and clamps.

CONCLUSIONS The dynamic telescopic craniotomy technique with the novel cranial fixation plate provides superior control of ICP after an abrupt increase in intracranial volume as compared with the standard craniotomy and hinge craniotomy techniques.

http://thejns.org/doi/abs/10.3171/2015.6.JNS15706

KEY WORDS cerebral swelling; traumatic brain injury; malignant stroke; decompressive craniectomy; intracranial hypertension; edema; hemorrhage; cranial fixation; surgical technique

$\mathrm{I}$ NTRACRANIAL pressure (ICP) elevation is frequently encountered in severe traumatic brain injury, $, 1,4,8,10,13,16,17$, 27,47-49,51,69 malignant strokes, ${ }^{20,32,37,38,40,41,61,62,71,72,78}$ aneurysmal subarachnoid hemorrhage, $8,29,39,44,53,59,66,74,78$ intracerebral hemorrhage, ${ }^{18,30,35,40,55,58,78,80}$ and brain tumors. ${ }^{21,56}$ Uncontrollably elevated ICP has also been associated with poor patient outcomes. ${ }^{16-18,29,35,39,44,48,51,58,61,66,78}$ Several universally accepted guidelines have been developed for the treatment of patients with elevated ICP, including hyper- osmolar therapy, transient hyperventilation, barbiturates, ventricular drainage, craniotomy for mass lesions, and decompressive craniectomy. $6,7,36,50,76$

Decompressive craniectomy has been shown to be efficacious in the management of malignant cerebral and cerebellar strokes, ${ }^{31,37,38,41,52,71,72,76}$ aneurysmal subarachnoid hemorrhage, ${ }^{8,25,54,59,63,64}$ cerebral hemorrhage, ${ }^{28,30,40,67}$ and cerebral venous thrombosis.,.$^{2,73}$ However, the efficacy of decompressive craniectomy in traumatic brain injury

ABBREVIATIONS DECRA = Decompressive Craniectomy in Diffuse Traumatic Brain Injury; ICP = intracranial pressure; PEEK = polyetheretherketone.

SUBMITTED April 2, 2015. ACCEPTED June 3, 2015.

INCLUDE WHEN CITING Published online December 11, 2015; DOI: 10.3171/2015.6.JNS15706. 
remains debatable. $1,4,8,10-13,19,26,27,33,34,45,68,69,77$ While the Decompressive Craniectomy in Diffuse Traumatic Brain Injury (DECRA) trial showed that bilateral decompressive craniectomies were effective in reducing ICP from diffuse traumatic injuries, it failed to show an improved patient outcome..$^{13}$ The DECRA outcome failure is thought to be related to the significant surgical morbidity associated with the decompressive craniectomy procedure as well as the subsequent cranioplasty that is required in surviving patients. ${ }^{13,32,33}$ Decompressive craniectomy carries a complication risk of $37 \%-50 \%, 5,13,32,79$ and patients undergoing a cranioplasty for the repair of a craniectomy defect face an additional $16 \%-34 \%$ complication risk. $3,9,14,23,24,46,57,65,75$ One caveat regarding the DECRA trial is that only patients without any significant mass lesions were enrolled..$^{13}$ Some studies seem to suggest that a craniectomy may improve outcome when used for the treatment of elevated ICP associated with a mass lesion. ${ }^{12,27,28,45}$ The hinge craniotomy procedure has also gained recent support, as it provides for cranial decompression without removal of the bone flap. . $2,40-42,60^{2}$

Herein we describe the dynamic telescopic craniotomy procedure, which provides cranial decompression without removal of the bone flap using a novel fixation plate that allows for outward movement. The feasibility of this procedure in controlling postcraniotomy ICP elevation is also evaluated in cadaver skulls.

\section{Methods}

\section{Dynamic Telescopic Plate Characteristics}

The dynamic telescopic craniotomy plate (Figs. 1-4) composes 2 semicircular-shaped plates containing holes for the placement of screws into the bone flap on 1 side and into the skull on the other side. The plates are connected through a telescopic portion in the center, which resides in the bur hole for a low profile. The central telescopic portion allows 1 plate to slide outward relative to the other

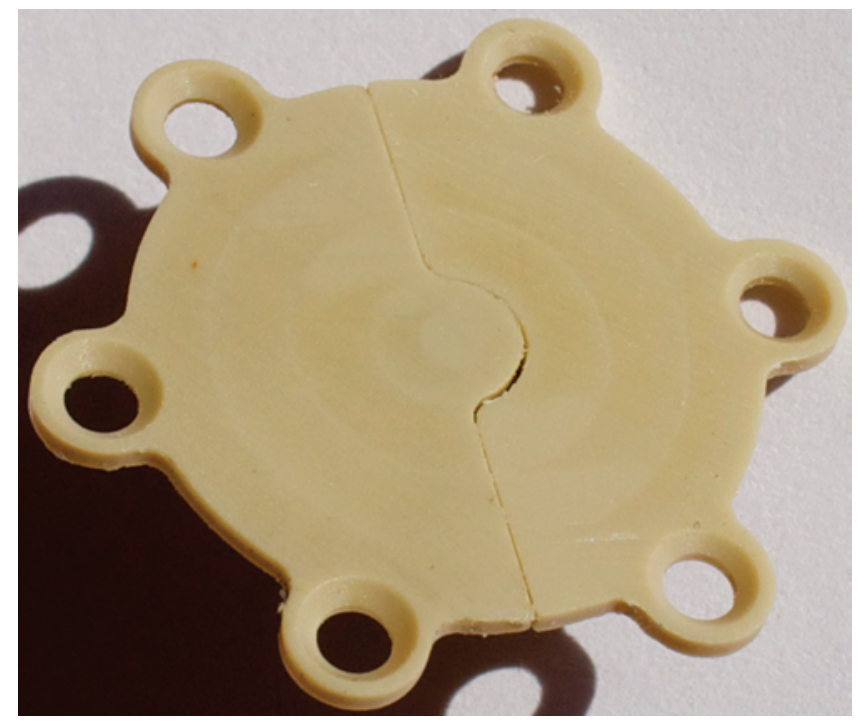

FIG. 1. Top-view photograph of the dynamic telescopic plate. Figure is available in color online only.

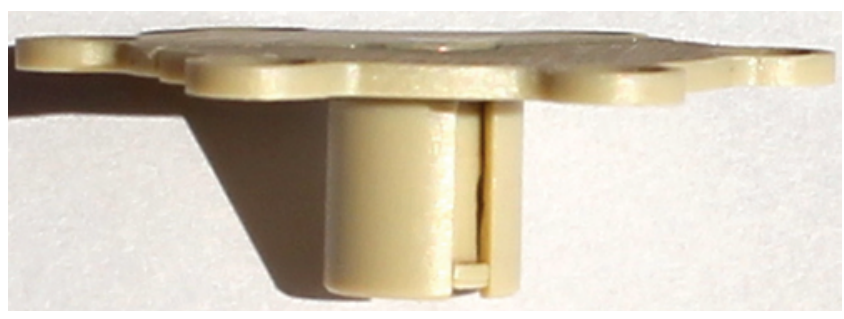

FIG. 2. Side-view photograph of the dynamic telescopic plate in a retracted position. Figure is available in color online only.

plate but does not allow it to slide inward below the level of the other plate. The telescopic portions are linked with hooks to prevent them from pulling apart completely. The plate connected to the bone flap translates outwards relative to the plate connected to the cranium with minimal intracranial tension on the bone flap; this allows outward movement of the bone flap relative to the cranium but does not allow the bone flap to sink inside the cranium once ICP normalizes. The telescopic portion allows up to 10.4 $\mathrm{mm}$ of outward bone-flap migration and has a length of $7 \mathrm{~mm}$ in the contracted state. Since the average human skull has a thickness of $7.4 \mathrm{~mm}$ in the frontal portion and $9.5 \mathrm{~mm}$ in the occipital portion, ${ }^{15}$ the plate maintains a low profile without creating epidural compression of the telescopic portion when placed in a bur hole of the skull at least $7 \mathrm{~mm}$ thick. The plates are made from either titanium or polyetheretherketone (PEEK).

\section{Specimen Preparation}

Five human cadaveric skull specimens were obtained from 3 women and 2 men who at the time of death ranged in age from 70 to 87 years (mean 79 years). Specimens were obtained fresh frozen and thawed in a bath of normal saline at $30^{\circ} \mathrm{C}$. The skull cap was attached to a block of laminated wood with rigid fixation so as not to allow any movement of the skull cap relative to the board, similar to the biomechanical skull-testing method described by Lerch. ${ }^{43}$

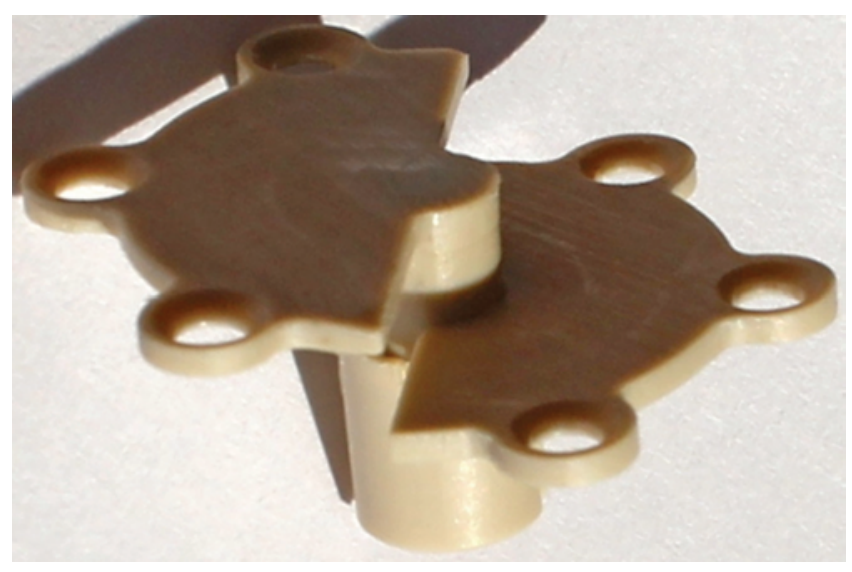

FIG. 3. Side-view photograph of the dynamic telescopic plate with the telescopic portions partially expanded. Figure is available in color online only. 


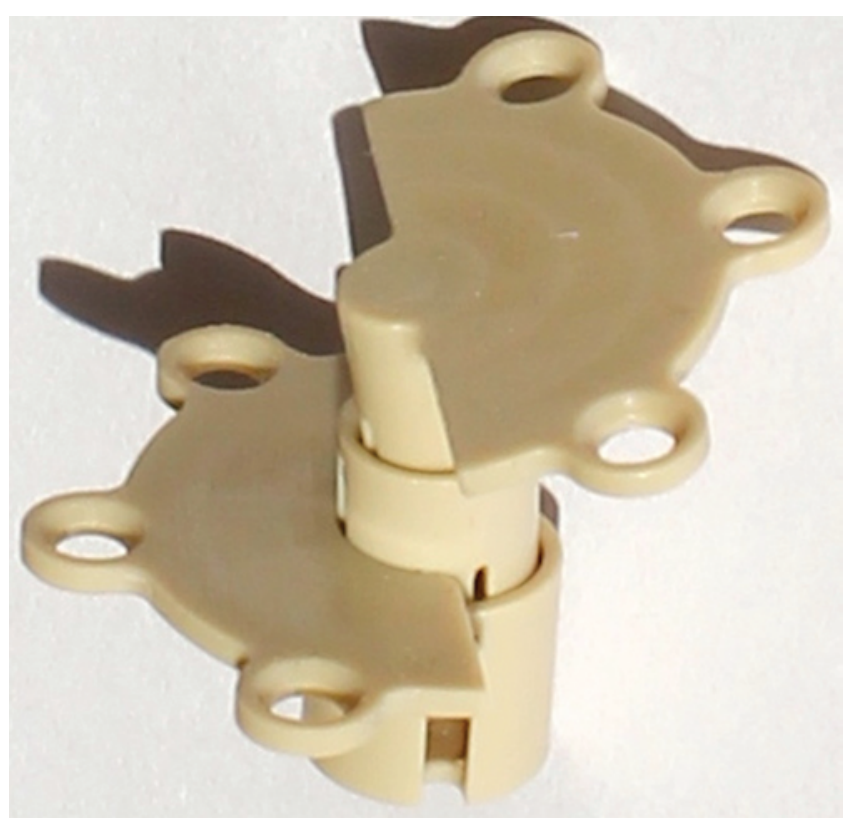

FIG. 4. Side-view photograph of the dynamic telescopic plate with the telescopic portions fully expanded. Figure is available in color online only.

\section{Surgical Technique}

A craniotomy with an approximately $10-\mathrm{cm}$ bone flap was performed in each specimen. The bone flap was then fixed to the skull using 3 to 4 dynamic telescopic plates that covered the bur holes (Fig. 5). To allow for effortless outward movement of the bone flap on all sides, the telescopic plates need to be placed relatively parallel to each other. If the plates are not parallel to one another, then only 1 side of the bone flap can move outward when an increase in ICP occurs. The parallel positioning of the plates can be difficult at times given the curved shape of the skull. At the beginning of the craniotomy, attempts should be made to position the bur holes (where the telescopic plates will be placed) in the relatively flat portions of the skull. For standard hemicraniectomy and bilateral craniectomy techniques, we recommend placing the implants in the frontal and parietal regions closer to the midline. This portion of the skull is relatively flatter and thicker. The temporal bone is usually very thin and is not ideal for implant placement since the skull has to be $7 \mathrm{~mm}$ thick to avoid dural indentation from the telescopic portion. In the bone flaps where the skull curvature was more pronounced, we used a modified hinge technique with 2 dynamic telescopic plates on 1 side and standard cranial fixation straight plates on the other side (Fig. 6). The straight plates were secured only to the bone flap to prevent the bone flap from settling inside the skull. To facilitate scalp expansion with outward migration of the bone flap, we recommend placing several slits in the galea and also degloving the scalp from the pericranium adjacent to the craniotomy.

\section{Plate Testing}

Simulation of cerebral swelling was achieved with a tissue expander (Mentor Worldwide, Inc.) inserted inside
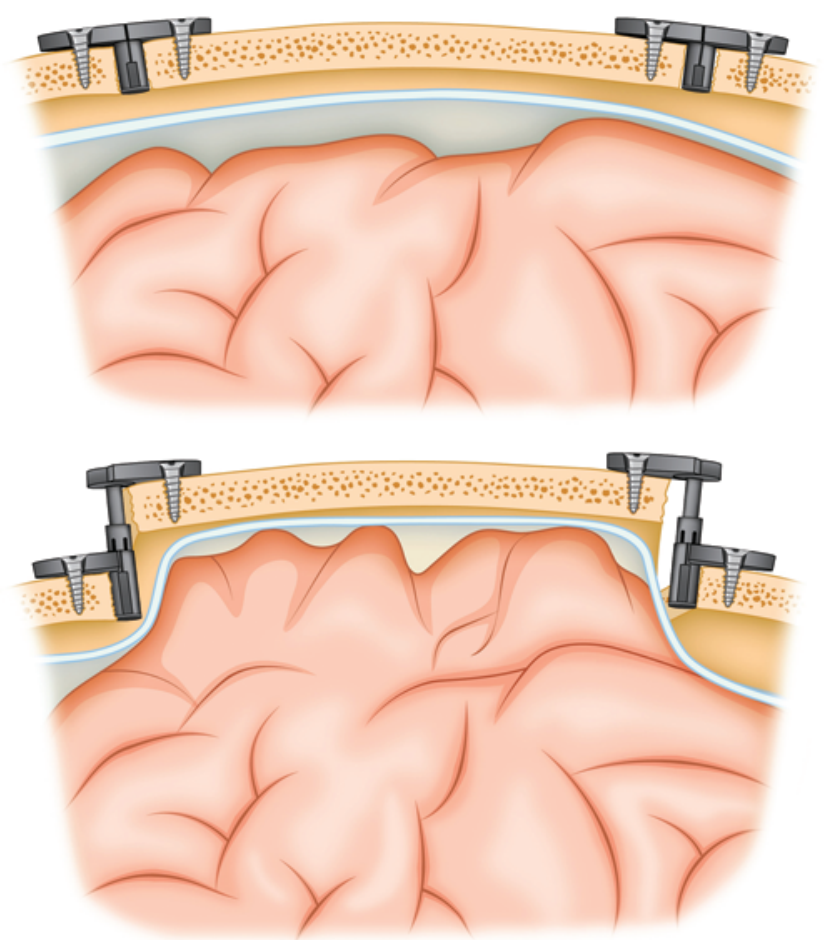

FIG. 5. Illustration of the dynamic telescopic craniotomy technique. Upper: Image illustrates the bone flap in an anatomical position with the dynamic telescopic plates covering the bur holes. Lower: Image illustrates the outward migration of the bone flap that occurs with brain swelling. The dynamic telescopic plates are in an expanded position. Copyright Rohit Khanna, Elsevier Illustration Service. Published with permission. Figure is available in color online only.

the skull prior to replacement of the bone flap. The tissue expander comprised tubing through which saline was injected with a syringe. The pressure inside the skull was recorded with a digital manometer (Pyle).

Testing of the dynamic telescopic plate was performed with the bone flaps attached to the skulls using 3-4 dynamic plates covering the bur holes (Fig. 7). In skulls with pronounced curvature of the bone flap, 2 dynamic plates were placed on 1 side of the bone flap and 2 straight plates secured only to the bone flap were placed on the other side to prevent the bone flap from sinking (Fig. 8), similar to the hinge craniotomy technique (Fig. 9). The tissue expander was serially dilated and the ICP was recorded. We allowed the free-floating end to elevate up to $10 \mathrm{~mm}$.

The hinge craniotomy technique was tested in another set of evaluations. The bone flaps were attached to the skulls using a Y-shaped (Synthes, Inc.) plate on 1 side of the bone flap and 2 straight plates secured only to the bone flap on the other side to prevent bone-flap sinking. The tissue expander was serially dilated and the ICP was recorded. The free-floating end of the bone flap was allowed to elevate up to $10 \mathrm{~mm}$. To maintain uniformity between the dynamic craniotomy and the hinge craniotomy evaluations, the free-floating ends from both techniques were allowed to elevate to $10 \mathrm{~mm}$.

We also evaluated the standard craniotomy technique using fixed cranial plates. The bone flap was attached to 

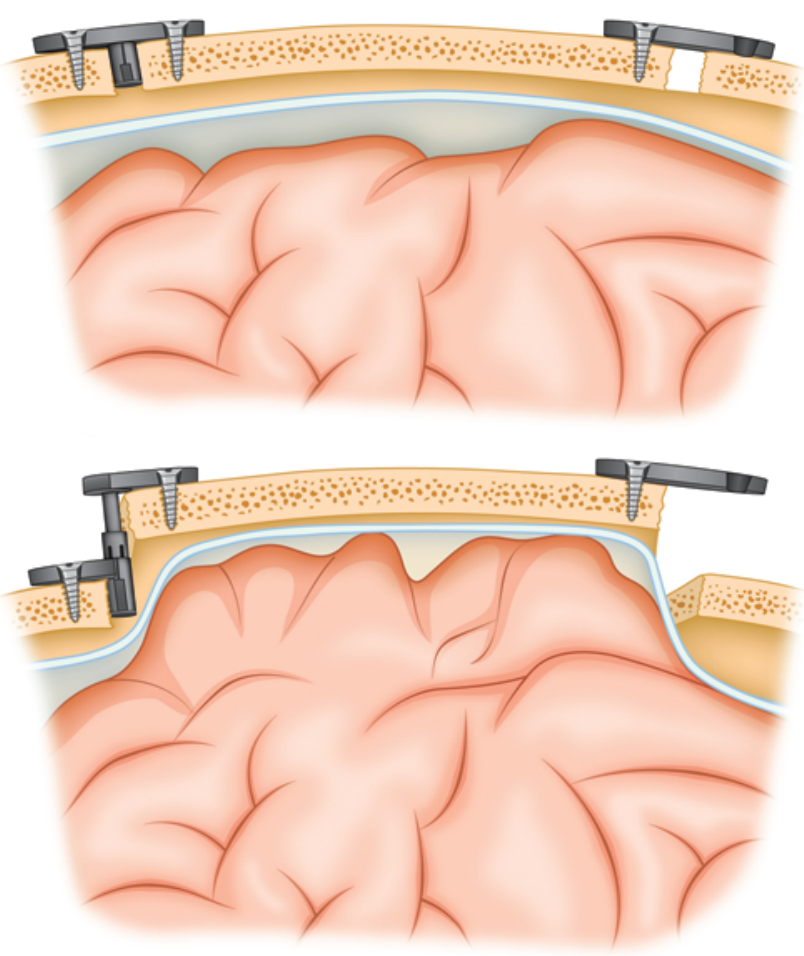

FIG. 6. Illustration of the modified hinge craniotomy technique. Upper: Image illustrates the bone flap in an anatomical position with the dynamic telescopic plates covering the bur holes on the left side combined with a straight plate secured to the bone flap on the right side, which prevents the bone flap from sinking. Lower: Image illustrates the outward migration of the bone flap that occurs with brain swelling. The dynamic telescopic plate is in an expanded position and allows outward bone flap migration at both ends. Copyright Rohit Khanna, Elsevier IIlustration Service. Published with permission. Figure is available in color online only.

the skull with 3 rigid cranial fixation plates (Synthes, Inc.). The tissue expander inside the skull was then sequentially dilated with incremental injections of saline, and the ICP was recorded after each injection until the ICP approached $100 \mathrm{~mm} \mathrm{Hg}$.

Biomechanical evaluation of the dynamic plate using load-bearing tests was performed by applying a quasi-static compressive force onto each implant until an impression depth of $2 \mathrm{~mm}$ was reached. To accomplish this, each implanted plate was mounted to the test platform of an electromechanical materials test machine (MTS Corp.), and a compressive load under displacement control (set to a maximum of $2 \mathrm{~mm}$ at a rate of $5 \mathrm{~mm} / \mathrm{min}$ ) was applied by a pushrod that was connected to the crosshead of the test machine. The pushrod was connected to the actuator using a minimal friction universal joint that allowed for unconstrained bending and torsion to ensure that the axis of the pushrod was perpendicular to the implant, thus providing maximum compressive displacement of the bone flap relative to the skull.

\section{Results}

The results of the rigid-plate cranial fixation and the

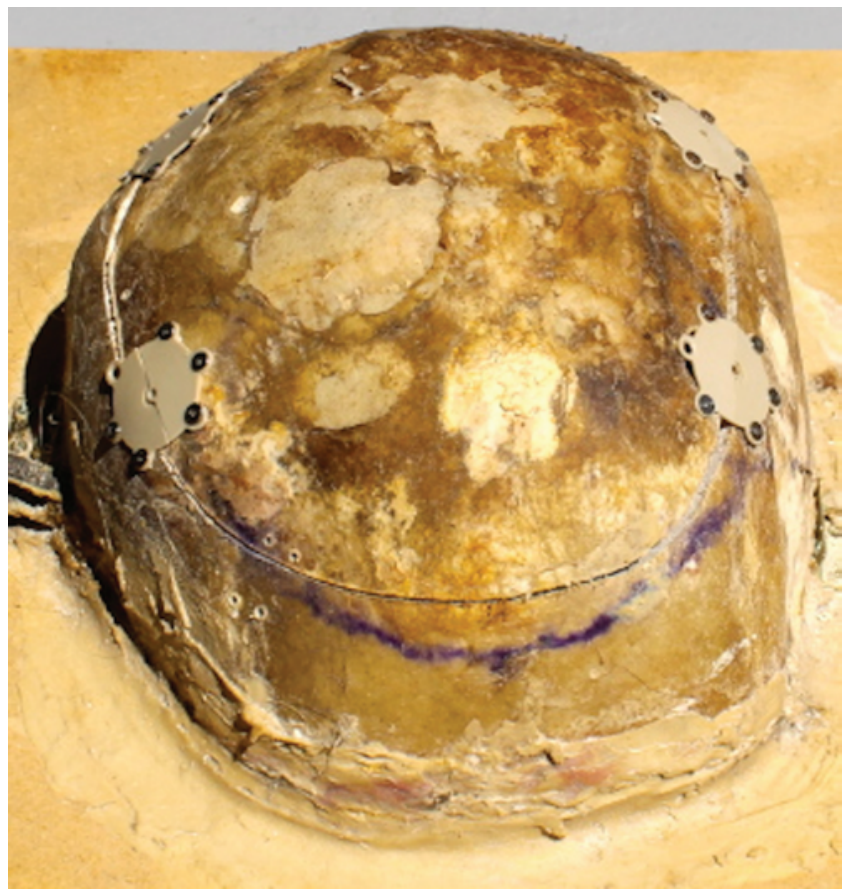

FIG. 7. Photograph of a cadaver skull mounted on a board for testing with the bone flap secured using 4 dynamic telescopic plates. Figure is available in color online only.

dynamic telescopic craniotomy are summarized in Table 1. With increasing intracranial volume, the ICP incrementally rises until reaching a threshold in which the ICP rises significantly higher after a much smaller increase in intracranial volume. With a standard fixed plate, after reaching an intracranial volume threshold of $120 \mathrm{ml}$ above baseline, the ICP increased from a mean of $11.4 \mathrm{~mm} \mathrm{Hg}$ to $23.9 \mathrm{~mm} \mathrm{Hg}$ with an additional $40 \mathrm{ml}$ of intracranial volume. A mean ICP of $100.1 \mathrm{~mm} \mathrm{Hg}$ was observed with

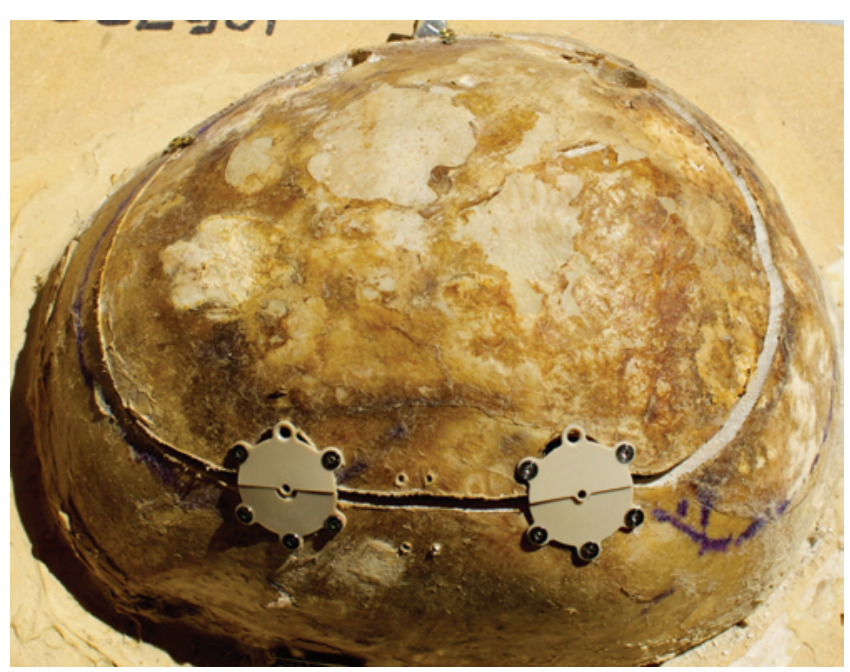

FIG. 8. Photograph of a bone flap in a cadaver skull secured using 2 dynamic telescopic plates on the left side and 2 straight plates on the right side. The straight plates are secured only to the bone flap, reflective of the modified hinge craniotomy technique. Figure is available in color online only. 


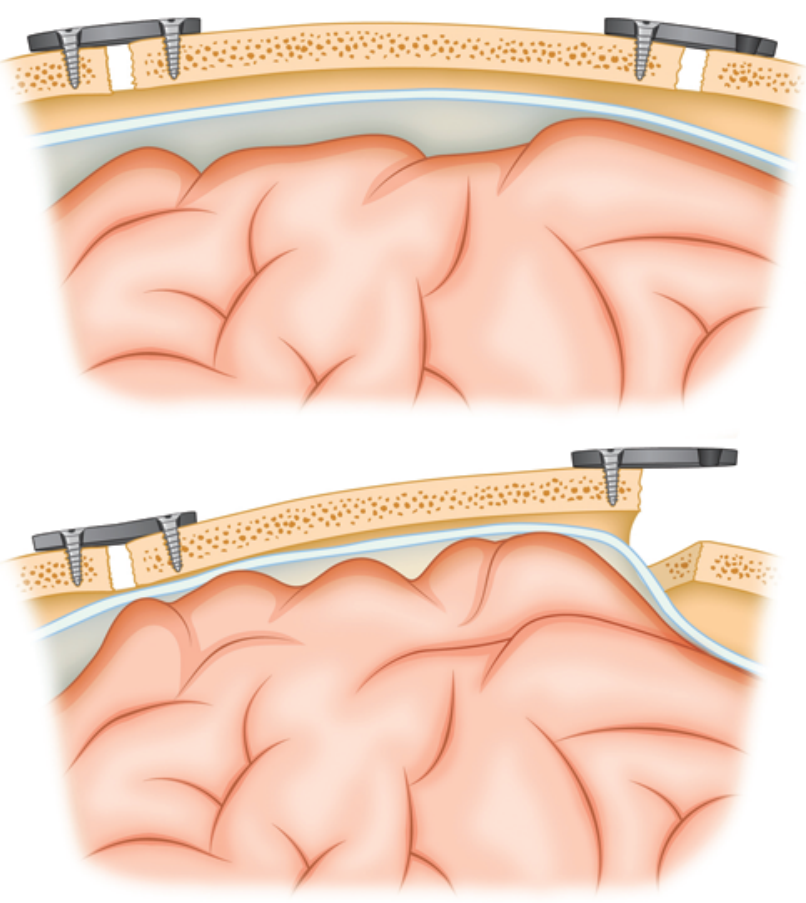

FIG. 9. Illustration of the hinge craniotomy technique. The straight plate on the left side secures the bone flap with the hinge end to the skull. The straight plate on the right side is secured only to the bone flap, creating a free-floating end. Upper: The anatomical position of the bone flap. Lower: Outward movement of the bone flap at the free-floating end that occurs with brain swelling. The restricted hinged end on the left side does not allow outward migration of the bone flap and limits the extent of intracranial volume expansion. Copyright Rohit Khanna, Elsevier Illustration Service. Published with permission. Figure is available in color online only.

the addition of $240 \mathrm{ml}$ of intracranial volume using the fixed plates. However, a significant increase in intracranial expansion after a progressive volume increase was seen with the dynamic craniotomy when compared with rigid bone flap fixation. Outward migration of the bone flap was associated with progressive increases in intracranial volume (Fig. 10). Incremental increases in intracranial volume resulted in an ICP within the normal range $(<14$

TABLE 1. Comparative analysis of ICP compliance upon changes in intracranial volume between the standard craniotomy and dynamic telescopic craniotomy techniques

\begin{tabular}{cccc}
\hline $\begin{array}{c}\text { Intracranial Vol } \\
\begin{array}{c}\text { Above Baseline } \\
(\mathrm{ml})\end{array}\end{array}$ & $\begin{array}{c}\text { Standard } \\
\text { Fixed-Plate ICP } \\
(\text { mean mm Hg) }\end{array}$ & $\begin{array}{c}\text { Dynamic } \\
\text { Telescopic Plate } \\
\text { ICP (mean mm Hg) }\end{array}$ & p Value* \\
\hline 40 & 2.20 & 1.04 & 0.022 \\
\hline 80 & 5.48 & 1.46 & 0.015 \\
\hline 120 & 11.42 & 2.88 & 0.046 \\
\hline 160 & 23.90 & 4.18 & 0.009 \\
\hline 180 & 44.84 & 4.86 & 0.017 \\
\hline 200 & 62.06 & 6.40 & 0.012 \\
\hline 220 & 76.05 & 10.04 & 0.016 \\
\hline 240 & 100.17 & 13.42 & 0.023 \\
\hline
\end{tabular}

\footnotetext{
* Paired Student t-test.
}

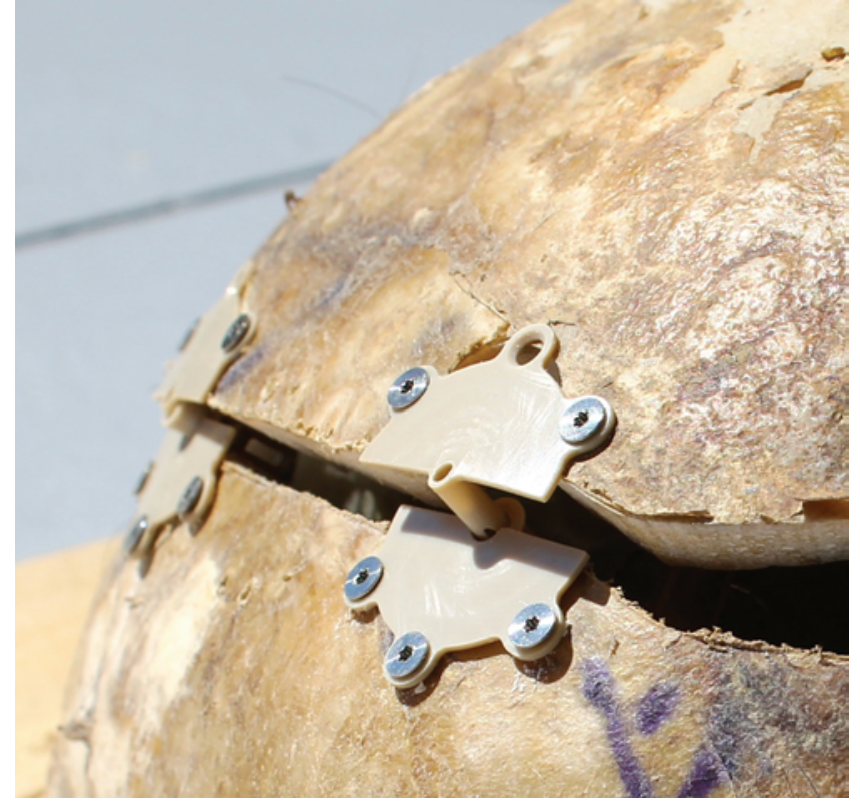

FIG. 10. Photograph of a cadaver skull illustrating how bone-flap elevation is enabled by the expanded dynamic telescopic plates during an increase in intracranial volume. Figure is available in color online only.

$\mathrm{mm} \mathrm{Hg}$ ) when dynamic telescopic plates were used, while the use of rigid fixation plates resulted in the ICP ranging from 44.8 to $100.1 \mathrm{~mm} \mathrm{Hg}$ (Fig. 11) . The dynamic plate allowed for an additional $120 \mathrm{ml}$ of intracranial volume compared with the fixed plate while maintaining a normal ICP. No screw pullout, plate failure, or breakage was noted, despite subjecting the telescopic plates to repetitive expansion and retractions. The compliance of the telescopic plate is evident with maintenance of a normal ICP despite abrupt increases in intracranial volume, as would be seen

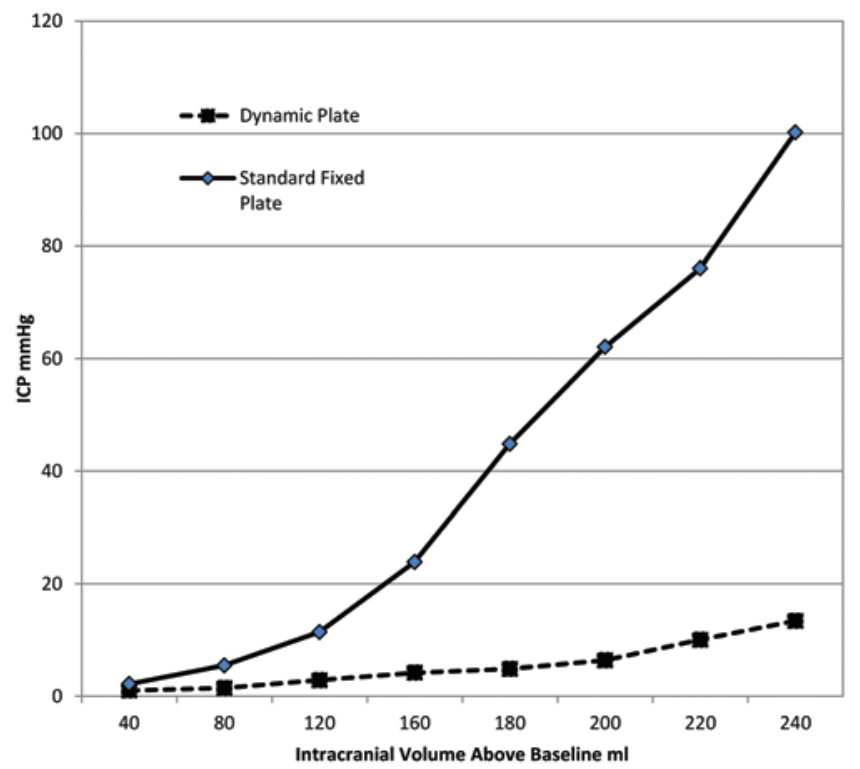

FIG. 11. Graphic depiction of the association between intracranial volume and ICP using fixed cranial plates versus dynamic telescopic plates. Figure is available in color online only. 
in a clinical setting of an acute postoperative hemorrhage or significant cerebral swelling.

The hinge craniotomy technique was also effective in ICP reduction when compared with the standard craniotomy, as summarized in Table 2. Table 3 shows the comparative results between dynamic craniotomy and hinge craniotomy techniques. The dynamic craniotomy allowed for an additional $40 \mathrm{ml}$ of intracranial volume over the hinge craniotomy, while maintaining the ICP in a normal range. A comparative analysis of the 2 techniques showed a statistically significant decrease in ICP associated with intracranial volume increases of 160 to $240 \mathrm{ml}$ when using the dynamic craniotomy over the hinge craniotomy. Both techniques provided equivalent ICP control up until an intracranial volume increase of $120 \mathrm{ml}$; however, when the increase exceeds $120 \mathrm{ml}$, the dynamic craniotomy technique was superior to the hinge craniotomy technique in maintaining a normal ICP (Fig. 12).

Biomechanical testing revealed that the dynamic plates prevented bone-flap sinking better than the tested fixation plates and clamps commercially available.

\section{Discussion}

The procedure and feasibility of the dynamic telescopic craniotomy technique with the use of novel telescopic plates has been described herein. A characteristic of the dynamic craniotomy plate is the capability for translational movement of the bone flap to accommodate an increase in intracranial volume as would be encountered with a hemorrhage or cerebral swelling. The advantage of this procedure over a hinged craniotomy is that it allows for outward constrained bone flap movement without a restricted hinged end, thereby providing increased intracranial volume expansion. Another advantage of the dynamic plate over the hinged plate technique is that it also covers the bur hole and prevents the bone flap from sinking inside the skull, avoiding a cosmetic skull defect.

A hinged frontal bone elevation of $10 \mathrm{~mm}$ can lead to at least a $6 \%$ increase in the total cranial capacity ${ }^{70}$ and one can expect a greater increase in cranial capacity using the dynamic craniotomy, which does not have any hinged ends. The intracranial volume gained by the hinge

TABLE 2. Comparative analysis of ICP compliance upon changes in intracranial volume between the standard craniotomy and hinge craniotomy techniques

\begin{tabular}{cccc}
\hline $\begin{array}{c}\text { Intracranial Vol } \\
\begin{array}{c}\text { Above Baseline } \\
(\mathrm{ml})\end{array}\end{array}$ & $\begin{array}{c}\text { Standard Fixed } \\
\text { Plate ICP } \\
\text { (mean mm Hg) }\end{array}$ & $\begin{array}{c}\text { Hinge Plate ICP } \\
\text { (mean mm Hg) }\end{array}$ & p Value* \\
\hline 40 & 2.20 & 0.98 & 0.014 \\
\hline 80 & 5.48 & 1.32 & 0.015 \\
\hline 120 & 11.42 & 3.44 & 0.063 \\
\hline 160 & 23.90 & 5.26 & 0.010 \\
\hline 180 & 44.84 & 8.36 & 0.025 \\
\hline 200 & 62.06 & 15.98 & 0.024 \\
\hline 220 & 76.05 & 20.32 & 0.018 \\
\hline 240 & 100.17 & 31.80 & 0.045 \\
\hline
\end{tabular}

* Paired Student t-test.
TABLE 3. Comparative analysis of ICP compliance upon changes in intracranial volume between the dynamic telescopic craniotomy and hinge craniotomy techniques

\begin{tabular}{cccc}
\hline $\begin{array}{c}\text { Intracranial Vol } \\
\begin{array}{c}\text { Above Baseline } \\
(\mathrm{ml})\end{array}\end{array}$ & $\begin{array}{c}\text { Dynamic } \\
\text { Telescopic } \\
\text { Plate ICP } \\
\text { (mean mm Hg) }\end{array}$ & $\begin{array}{c}\text { Hinge Plate ICP } \\
\text { (mean mm Hg) }\end{array}$ & p Value* \\
\hline 40 & 1.04 & 0.98 & 0.697 \\
\hline 80 & 1.46 & 1.32 & 0.263 \\
\hline 120 & 2.88 & 3.44 & 0.082 \\
\hline 160 & 4.18 & 5.26 & 0.027 \\
\hline 180 & 4.86 & 8.36 & 0.005 \\
\hline 200 & 6.40 & 15.98 & 0.006 \\
\hline 220 & 10.04 & 20.32 & 0.030 \\
\hline 240 & 13.42 & 31.80 & 0.009 \\
\hline
\end{tabular}

* Paired Student t-test.

craniotomy or dynamic craniotomy technique can be calculated using a modification of the $\mathrm{ABC} / 2$ intracranial volume calculation formula. To incorporate the variation in the bone flap elevation at different ends, the following formula can be used: $\mathrm{A} \times \mathrm{B} \times([\mathrm{C}$ at shortest elevation + $\mathrm{C}$ at highest elevation]/2)/2. With a $10-\mathrm{cm}$ bone flap, a $10-$ $\mathrm{mm}$ bone flap elevation would allow for an extra $25 \mathrm{ml}$ of intracranial volume in a hinged craniotomy or an extra 50 $\mathrm{ml}$ in a dynamic craniotomy. Accordingly, in this scenario, a dynamic craniotomy would provide a $100 \%$ increase in intracranial volume when compared with a hinged craniotomy. This significant volume increase can hopefully decrease the risk of cerebral herniation and provide a favorable outcome for patients with high ICP.

Although the intracranial volume used in this study model does not reflect a true intracranial volume since

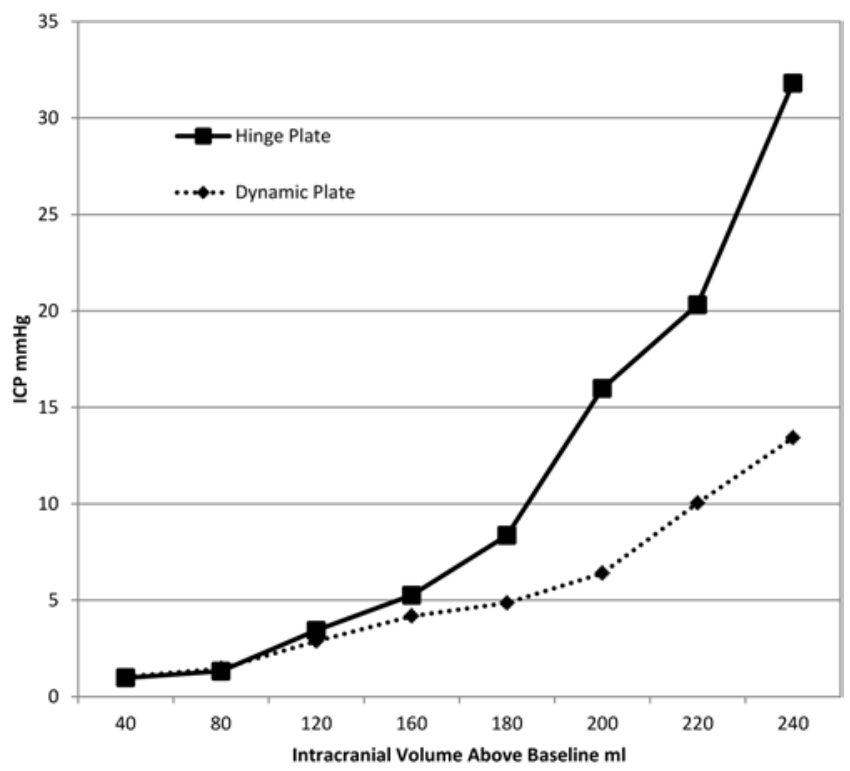

FIG. 12. Graphic depiction of the association between intracranial volume and ICP using a hinge craniotomy versus the dynamic telescopic plates. 
only skull caps were used, the Monro-Kellie doctrine is well depicted. The goal of the study was to test the functionality of the dynamic plate during an increase in intracranial volume, reflective of either a hemorrhage and/or cerebral swelling. After reaching an intracranial volume threshold, it is apparent that an increase in as little as $20 \mathrm{ml}$ in volume can lead to a very high ICP and risk of cerebral herniation when using fixed cranial plates or clamps for bone flap fixation. It is also evident that the use of dynamic plates allows ICP to remain at normal levels even with an abrupt increase in intracranial volume of $80 \mathrm{ml}$ beyond what would be tolerable with the use of fixed plates. A larger bone flap could provide for even higher intracranial volume increase compliance.

While the dynamic telescopic craniotomy is not meant to replace a decompressive craniectomy, it could potentially reduce the need for a craniectomy and provide another armamentarium in the management of postoperative elevated ICP caused by either a rehemorrhage or cerebral edema.

\section{Conclusions}

This study demonstrates the feasibility of a dynamic telescopic craniotomy with a novel plate used for postcraniotomy ICP control. The intracranial volume expansion provided by the low-profile plate allows for excellent control of ICP.

\section{References}

1. Aarabi B, Hesdorffer DC, Ahn ES, Aresco C, Scalea TM, Eisenberg HM: Outcome following decompressive craniectomy for malignant swelling due to severe head injury. J Neurosurg 104:469-479, 2006

2. Aaron S, Alexander M, Moorthy RK, Mani S, Mathew V, Patil AKB, et al: Decompressive craniectomy in cerebral venous thrombosis: a single centre experience. J Neurol Neurosurg Psychiatry 84:995-1000, 2013

3. Beauchamp KM, Kashuk J, Moore EE, Bolles G, Rabb C, Seinfeld J, et al: Cranioplasty after postinjury decompressive craniectomy: is timing of the essence? J Trauma 69:270274, 2010

4. Bor-Seng-Shu E, Figueiredo EG, Amorim RLO, Teixeira MJ, Valbuza JS, de Oliveira MM, et al: Decompressive craniectomy: a meta-analysis of influences on intracranial pressure and cerebral perfusion pressure in the treatment of traumatic brain injury. J Neurosurg 117:589-596, 2012

5. Bowers CA, Riva-Cambrin J, Hertzler DA II, Walker ML: Risk factors and rates of bone flap resorption in pediatric patients after decompressive craniectomy for traumatic brain injury. J Neurosurg Pediatr 11:526-532, 2013

6. Brain Trauma Foundation, American Association of Neurological Surgeons, Congress of Neurological Surgeons: Guidelines for the management of severe traumatic brain injury. J Neurotrauma 24 (Suppl 1):S1-S106, 2007 (Erratum in J Neurotrauma 25:276-278, 2008)

7. Bullock MR, Chesnut R, Ghajar J, Gordon D, Hartl R, Newell DW, et al: Guidelines for the surgical management of traumatic brain injury. Neurosurgery 58 (3 Suppl):1-62, 2006

8. Burger R, Duncker D, Uzma N, Rohde V: Decompressive craniotomy: durotomy instead of duroplasty to reduce prolonged ICP elevation. Acta Neurochir Suppl 102:93-97, 2008

9. Chang V, Hartzfeld P, Langlois M, Mahmood A, Seyfried D: Outcomes of cranial repair after craniectomy. J Neurosurg 112:1120-1124, 2010
10. Chibbaro S, Marsella M, Romano A, Ippolito S, Benericetti E: Combined internal uncusectomy and decompressive craniectomy for the treatment of severe closed head injury: experience with 80 cases. J Neurosurg 108:74-79, 2008 (Erratum in J Neurosurg 111:884, 2009)

11. Cho DY, Wang YC, Chi CS: Decompressive craniotomy for acute shaken/impact baby syndrome. Pediatr Neurosurg 23:192-198, 1995

12. Compagnone C, Murray GD, Teasdale GM, Maas AI, Esposito D, Princi P, et al: The management of patients with intradural post-traumatic mass lesions: a multicenter survey of current approaches to surgical management in 729 patients coordinated by the European Brain Injury Consortium. Neurosurgery 57:1183-1192, 2005

13. Cooper DJ, Rosenfeld JV, Murray L, Arabi YM, Davies AR, D'Urso P, et al: Decompressive craniectomy in diffuse traumatic brain injury. N Engl J Med 364:1493-1502, 2011

14. Dünisch P, Walter J, Sakr Y, Kalff R, Waschke A, Ewald C: Risk factors of aseptic bone resorption: a study after autologous bone flap reinsertion due to decompressive craniotomy. J Neurosurg 118:1141-1147, 2013

15. Ebraheim NA, Liu J, Patil V, Sanford CG Jr, Crotty MJ, Haman SP, et al: Evaluation of skull thickness and insertion torque at the halo pin insertion areas in the elderly: a cadaveric study. Spine J 7:689-693, 2007

16. Farahvar A, Gerber LM, Chiu YL, Carney N, Härtl R, Ghajar $\mathrm{J}$ : Increased mortality in patients with severe traumatic brain injury treated without intracranial pressure monitoring. J Neurosurg 117:729-734, 2012

17. Farahvar A, Gerber LM, Chiu YL, Härtl R, Froelich M, Carney N, et al: Response to intracranial hypertension treatment as a predictor of death in patients with severe traumatic brain injury. J Neurosurg 114:1471-1478, 2011 (Erratum in J Neurosurg 115:191, 2011)

18. Fernandes HM, Siddique S, Banister K, Chambers I, Wooldridge T, Gregson B, et al: Continuous monitoring of ICP and CPP following ICH and its relationship to clinical, radiological and surgical parameters. Acta Neurochir Suppl 76:463-466, 2000

19. Figaji AA, Fieggen AG, Peter JC: Early decompressive craniotomy in children with severe traumatic brain injury. Childs Nerv Syst 19:666-673, 2003

20. Frank JI: Large hemispheric infarction, deterioration, and intracranial pressure. Neurology 45:1286-1290, 1995

21. Gelb AW, Craen RA, Rao GSU, Reddy KR, Megyesi J, Mohanty $\mathrm{B}$, et al: Does hyperventilation improve operating condition during supratentorial craniotomy? A multicenter randomized crossover trial. Anesth Analg 106:585-594, 2008

22. Goettler CE, Tucci KA: Decreasing the morbidity of decompressive craniectomy: the Tucci flap. J Trauma 62:777-778, 2007

23. Gooch MR, Gin GE, Kenning TJ, German JW: Complications of cranioplasty following decompressive craniectomy: analysis of 62 cases. Neurosurg Focus 26(6):E9, 2009

24. Grant GA, Jolley M, Ellenbogen RG, Roberts TS, Gruss JR, Loeser JD: Failure of autologous bone-assisted cranioplasty following decompressive craniectomy in children and adolescents. J Neurosurg 100 (2 Suppl Pediatrics):163-168, 2004

25. Güresir E, Schuss P, Vatter H, Raabe A, Seifert V, Beck J: Decompressive craniectomy in subarachnoid hemorrhage. Neurosurg Focus 26(6):E4, 2009

26. Güresir E, Vatter H, Schuss P, Oszvald A, Raabe A, Seifert V, et al: Rapid closure technique in decompressive craniectomy. J Neurosurg 114:954-960, 2011

27. Hartings JA, Vidgeon S, Strong AJ, Zacko C, Vagal A, Andaluz N, et al: Surgical management of traumatic brain injury: a comparative-effectiveness study of 2 centers. J Neurosurg 120:434-446, 2014

28. Hayes SB, Benveniste RJ, Morcos JJ, Aziz-Sultan MA, 
Elhammady MS: Retrospective comparison of craniotomy and decompressive craniectomy for surgical evacuation of nontraumatic, supratentorial intracerebral hemorrhage. Neurosurg Focus 34(5):E3, 2013

29. Heuer GG, Smith MJ, Elliott JP, Winn HR, LeRoux PD: Relationship between intracranial pressure and other clinical variables in patients with aneurysmal subarachnoid hemorrhage. J Neurosurg 101:408-416, 2004

30. Heuts SG, Bruce SS, Zacharia BE, Hickman ZL, Kellner CP, Sussman ES, et al: Decompressive hemicraniectomy without clot evacuation in dominant-sided intracerebral hemorrhage with ICP crisis. Neurosurg Focus 34(5):E4, 2013

31. Hofmeijer J, Kappelle LJ, Algra A, Amelink GJ, van Gijn J, van der Worp HB: Surgical decompression for space-occupying cerebral infarction (the Hemicraniectomy After Middle Cerebral Artery infarction with Life-threatening Edema Trial [HAMLET]): a multicentre, open, randomised trial. Lancet Neurol 8:326-333, 2009

32. Honeybul S, Ho KM: Long-term complications of decompressive craniectomy for head injury. J Neurotrauma 28:929-935, 2011

33. Honeybul S, Ho KM, Lind CR: What can be learned from the DECRA study. World Neurosurg 79:159-161, 2013

34. Honeybul S, Janzen C, Kruger K, Ho KM: Decompressive craniectomy for severe traumatic brain injury: is life worth living? J Neurosurg 119:1566-1575, 2013

35. Janny P, Papo I, Chazal J, Colnet G, Barretto LC: Intracranial hypertension and prognosis of spontaneous intracerebral haematomas. A correlative study of 60 patients. Acta Neurochir (Wien) 61:181-186, 1982

36. Jauch EC, Saver JL, Adams HP Jr, Bruno A, Connors JJ, Demaerschalk BM, et al: Guidelines for the early management of patients with acute ischemic stroke: a guideline for healthcare professionals from the American Heart Association/ American Stroke Association. Stroke 44:870-947, 2013

37. Jüttler E, Schwab S, Schmiedek P, Unterberg A, Hennerici M, Woitzik J, et al: Decompressive Surgery for the Treatment of Malignant Infarction of the Middle Cerebral Artery (DESTINY): a randomized, controlled trial. Stroke 38:2518-2525, 2007

38. Jüttler E, Unterberg A, Woitzik J, Bösel J, Amiri H, Sakowitz OW, et al: Hemicraniectomy in older patients with extensive middle-cerebral-artery stroke. N Engl J Med 370:1091-1100, 2014

39. Kaye AH, Brownbill D: Postoperative intracranial pressure in patients operated on for cerebral aneurysms following subarachnoid hemorrhage. J Neurosurg 54:726-732, 1981

40. Kenning TJ, Gandhi RH, German JW: A comparison of hinge craniotomy and decompressive craniectomy for the treatment of malignant intracranial hypertension: early clinical and radiographic analysis. Neurosurg Focus 26(6):E6, 2009

41. Kenning TJ, Gooch MR, Gandhi RH, Shaikh MP, Boulos AS, German JW: Cranial decompression for the treatment of malignant intracranial hypertension after ischemic cerebral infarction: decompressive craniectomy and hinge craniotomy. J Neurosurg 116:1289-1298, 2012

42. Ko K, Segan S: In situ hinge craniectomy. Neurosurgery 60 (4 Suppl 2):255-259, 2007

43. Lerch KD: Reliability of cranial flap fixation techniques: comparative experimental evaluation of suturing, titanium miniplates, and a new rivet-like titanium clamp (CranioFix): technical note. Neurosurgery 44:902-905, 1999

44. Le Roux PD, Elliott JP, Downey L, Newell DW, Grady MS, Mayberg MR, et al: Improved outcome after rupture of anterior circulation aneurysms: a retrospective 10-year review of 224 good-grade patients. J Neurosurg 83:394-402, 1995

45. Li LM, Kolias AG, Guilfoyle MR, Timofeev I, Corteen EA, Pickard JD, et al: Outcome following evacuation of acute subdural haematomas: a comparison of craniotomy with decompressive craniectomy. Acta Neurochir (Wien) 154:1555-1561, 2012

46. Liang W, Xiaofeng Y, Weiguo L, Gang S, Xuesheng Z, Fei $\mathrm{C}$, et al: Cranioplasty of large cranial defect at an early stage after decompressive craniectomy performed for severe head trauma. J Craniofac Surg 18:526-532, 2007

47. Mangat HS, Chiu YL, Gerber LM, Alimi M, Ghajar J, Härtl R: Hypertonic saline reduces cumulative and daily intracranial pressure burdens after severe traumatic brain injury. $\mathbf{J}$ Neurosurg 122:202-210, 2015

48. Marmarou A, Anderson RL, Ward JD, Choi SC, Young HF, Eisenberg HM, et al: Impact of ICP instability and hypotension on outcome in patients with severe head trauma. J Neurosurg 75 Suppl:S59-S66, 1991

49. Miller JD, Becker DP, Ward JD, Sullivan HG, Adams WE, Rosner MJ: Significance of intracranial hypertension in severe head injury. J Neurosurg 47:503-516, 1977

50. Morgenstern LB, Hemphill JC III, Anderson C, Becker K, Broderick JP, Connolly ES Jr, et al: Guidelines for the management of spontaneous intracerebral hemorrhage: a guideline for healthcare professionals from the American Heart Association/American Stroke Association. Stroke 41:21082129,2010

51. Narayan RK, Kishore PR, Becker DP, Ward JD, Enas GG, Greenberg RP, et al: Intracranial pressure: to monitor or not to monitor? A review of our experience with severe head injury. J Neurosurg 56:650-659, 1982

52. Neugebauer H, Witsch J, Zweckberger K, Jüttler E: Spaceoccupying cerebellar infarction: complications, treatment, and outcome. Neurosurg Focus 34(5):E8, 2013

53. Nornes H, Magnaes B: Intracranial pressure in patients with ruptured saccular aneurysm. J Neurosurg 36:537-547, 1972

54. Otani N, Nawashiro H, Wada K, Nagatani K, Takeuchi S, Kobayashi H, et al: Surgical results after primary decompressive craniectomy in poor-grade aneurysmal subarachnoid hemorrhage. Acta Neurochir Suppl 118:269-272, 2013

55. Papo I, Janny P, Caruselli G, Colnet G, Luongo A: Intracranial pressure time course in primary intracerebral hemorrhage. Neurosurgery 4:504-511, 1979

56. Rasmussen M, Bundgaard H, Cold GE: Craniotomy for supratentorial brain tumors: risk factors for brain swelling after opening the dura mater. J Neurosurg 101:621-626, 2004

57. Rocque BG, Amancherla K, Lew SM, Lam S: Outcomes of cranioplasty following decompressive craniectomy in the pediatric population. J Neurosurg Pediatr 12:120-125, 2013

58. Ropper AH, King RB: Intracranial pressure monitoring in comatose patients with cerebral hemorrhage. Arch Neurol 41:725-728, 1984

59. Schirmer CM, Hoit DA, Malek AM: Decompressive hemicraniectomy for the treatment of intractable intracranial hypertension after aneurysmal subarachnoid hemorrhage. Stroke 38:987-992, 2007

60. Schmidt JH III, Reyes BJ, Fischer R, Flaherty SK: Use of hinge craniotomy for cerebral decompression. Technical note. J Neurosurg 107:678-682, 2007

61. Schwab S, Aschoff A, Spranger M, Albert F, Hacke W: The value of intracranial pressure monitoring in acute hemispheric stroke. Neurology 47:393-398, 1996

62. Schwarz S, Georgiadis D, Aschoff A, Schwab S: Effects of body position on intracranial pressure and cerebral perfusion in patients with large hemispheric stroke. Stroke 33:497-501, 2002

63. Smith ER, Carter BS, Ogilvy CS: Proposed use of prophylactic decompressive craniectomy in poor-grade aneurysmal subarachnoid hemorrhage patients presenting with associated large sylvian hematomas. Neurosurgery 51:117-124, 2002

64. Stapleton CJ, Walcott BP, Fusco MR, Butler WE, Thomas AJ, Ogilvy CS: Surgical management of ruptured middle 
cerebral artery aneurysms with large intraparenchymal or sylvian fissure hematomas. Neurosurgery 76:258-264, 2015

65. Stephens FL, Mossop CM, Bell RS, Tigno T Jr, Rosner MK, Kumar A, et al: Cranioplasty complications following wartime decompressive craniectomy. Neurosurg Focus 28(5):E3, 2010

66. Takeuchi S, Koike T, Sasaki O, Kamada K, Tanaka R, Arai $\mathrm{H}$ : Intracranial extradural pressure monitoring after direct operation on ruptured cerebral aneurysms. Neurosurgery 24:878-883, 1989

67. Takeuchi S, Wada K, Nagatani K, Otani N, Mori K: Decompressive hemicraniectomy for spontaneous intracerebral hemorrhage. Neurosurg Focus 34(5):E5, 2013

68. Taylor A, Butt W, Rosenfeld J, Shann F, Ditchfield M, Lewis E, et al: A randomized trial of very early decompressive craniectomy in children with traumatic brain injury and sustained intracranial hypertension. Childs Nerv Syst 17:154162,2001

69. Timmons SD, Ullman JS, Eisenberg HM: Craniectomy in diffuse traumatic brain injury. N Engl J Med 365:373-376, 2011 (Letter)

70. Traxler H, Ender HG, Weber G, Surd R, Redl H, Firbas W: Applying circular posterior-hinged craniotomy to malignant cerebral edemas. Clin Anat 15:173-181, 2002

71. Vahedi K, Hofmeijer J, Juettler E, Vicaut E, George B, Algra A, et al: Early decompressive surgery in malignant infarction of the middle cerebral artery: a pooled analysis of three randomised controlled trials. Lancet Neurol 6:215-222, 2007

72. Vahedi K, Vicaut E, Mateo J, Kurtz A, Orabi M, Guichard JP, et al: Sequential-design, multicenter, randomized, controlled trial of early decompressive craniectomy in malignant middle cerebral artery infarction (DECIMAL Trial). Stroke 38:2506-2517, 2007

73. Vivakaran TTR, Srinivas D, Kulkarni GB, Somanna S: The role of decompressive craniectomy in cerebral venous sinus thrombosis. J Neurosurg 117:738-744, 2012

74. Voldby B, Enevoldsen EM: Intracranial pressure changes following aneurysm rupture. Part 1: clinical and angiographic correlations. J Neurosurg 56:186-196, 1982

75. Walcott BP, Kwon CS, Sheth SA, Fehnel CR, Koffie RM, Asaad WF, et al: Predictors of cranioplasty complications in stroke and trauma patients. J Neurosurg 118:757-762, 2013
76. Wijdicks EFM, Sheth KN, Carter BS, Greer DM, Kasner SE, Kimberly WT, et al: Recommendations for the management of cerebral and cerebellar infarction with swelling: a statement for healthcare professionals from the American Heart Association/American Stroke Association. Stroke 45:12221238,2014

77. Woertgen C, Rothoerl RD, Schebesch KM, Albert R: Comparison of craniotomy and craniectomy in patients with acute subdural haematoma. J Clin Neurosci 13:718-721, 2006

78. Woodcock J, Ropper AH, Kennedy SK: High dose barbiturates in non-traumatic brain swelling: ICP reduction and effect on outcome. Stroke 13:785-787, 1982

79. Yang XF, Wen L, Shen F, Li G, Lou R, Liu WG, et al: Surgical complications secondary to decompressive craniectomy in patients with a head injury: a series of 108 consecutive cases. Acta Neurochir (Wien) 150:1241-1248, 2008

80. Ziai WC, Torbey MT, Naff NJ, Williams MA, Bullock R, Marmarou A, et al: Frequency of sustained intracranial pressure elevation during treatment of severe intraventricular hemorrhage. Cerebrovasc Dis 27:403-410, 2009

\section{Disclosures}

Dr. Khanna holds patents with NeuroVention LLC and CoolSpine LLC. Dr. Ferrara received research support from OrthoKinetic Technologies for the study described.

\section{Author Contributions}

Conception and design: Khanna. Acquisition of data: both authors. Analysis and interpretation of data: both authors. Drafting the article: Khanna. Critically revising the article: both authors. Reviewed submitted version of manuscript: both authors. Approved the final version of the manuscript on behalf of both authors: Khanna. Statistical analysis: Khanna. Study supervision: both authors.

\section{Correspondence}

Rohit Khanna, 311 N. Clyde Morris Blvd., Ste. 580, Daytona Beach, FL 32114. email: khanna.md@aol.com. 